\title{
THY1 Gene
}

National Cancer Institute

\section{Source}

National Cancer Institute. THY1 Gene. NCI Thesaurus. Code C73526.

This gene may be involved in the recognition of extracellular signals. 